\title{
Digital Manufacturing Enterprises as a Factor of Overcoming the Consequences of the Spread of COVID- 19 in the Regions
}

\author{
Donichev O.A.* Grachev S.A., Bykova M.L. \\ Vladimir State University named after Alexander Grigorievich and Nikolai Grigorievich Stoletovs, Vladimir, Russian \\ Federation \\ *Corresponding author. Email: donoa@vlsu.ru
}

\begin{abstract}
The coronavirus pandemic caused serious damage to most of the world's economies, and Russia is no exception. This means, that an effective mechanism, that will not only make up emersed losses but also achieve economic growth. The hypothesis of the study is the assumption, that the production orientation of the regions, based on industrial enterprises, actively using innovative digital technologies, will help overcome the emersed gap.

The performed work, based on the methods of statistical and comparative analysis, using economic and mathematical devices, made it possible to confirm the previously stated assumptions about the existing dependence of the economic achievements of the regions on the level of work of enterprises, that actively use digital technologies. The spread of digital technologies depends on the innovative orientation of the regions, which is formed as a result of the focused actions of regional authorities and business.
\end{abstract}

Keywords: digital enterprises, production orientation, regions, COVID-19, economic growth

\section{INTRODUCTION}

The economy of the Russian Federation, which has been in recession for the last 6 years, found itself in a critical situation as a result of the coronavirus pandemic. So the industrial production index for the first half of 2020 in relation to the same period in 2019 amounted to $96.5 \%$, for the same period 26.7 million square meters of housing were commissioned, which is $11.4 \%$ less than last year. According to Rosstat, the unemployment rate in July 2020 is $6.2 \%$ of the working-age population and amounted to 4.6 million people, consumer prices rose by $2.6 \%$.

In the second quarter of 2020, the real disposable income of the population fell by $8 \%$ compared to the previous year.

Over the first half of 2020 , overdue debt on residential loans increased to 2.42 billion rubles, almost 30 thousand families cannot pay their mortgage commitments. The statistics of coronavirus diseases practically do not decrease and exceed 5,000 people daily.

The measures, taken by the Government of the Russian Federation to reduce the ammount of infected people, to treat the sick people, as well as to support the economy pay off.

However, at the level of manufacturing enterprises, significant efforts are made to overcome the consequences of the economic crisis, including the one, caused by the pandemic
China, as known, was the first to suffer from COVID-19, it was also the first to relatively successfully overcome the consequences of the pandemic. A group of Russian and foreign scientists analyzed the impact of COVID-19 on the functioning of key sectors of the Chinese economy. Calculations were made for 31 provinces and 42 sectors of the economy. It was found, that the pandemic has a strong impact on carbon dioxide emissions, hazardous waste accumulation and energy efficiency ratings. Modeling financial and migration flows between the provinces of China made it possible to determine the most effective model for maintaining production and sales in a crisis. The main direction of the necessary measures is to prevent impingement of the recipients of state support. It is necessary to equally distribute the risks and losses among all the provinces of China. These measures will allow to incur the least losses and recover faster.

As for financial relations between Russia and China, the countries were strengthening cooperation. However, their further increase is difficult to predict. Moreover, as a result of the pandemic, there was a trend from the part of Russian companies to transfer existing manufacturing enterprises from China to Russia, which spurred on a new round of import substitution [1].

Meanwhile, it should be emphasized, that the Chinese economy, despite losses due to the coronavirus, maintained a positive dynamics. There is a completely different situation in Russia. First, it is necessary to overcome the emersed gap, and then embark on the path of sustainable development based on the production 
orientation of regions and the country as a whole, relying on innovative digital technologies from leading industrial enterprises and the manufacturing industry. The paradigm of sustainable development is attractive, because it provides for the ability to meet the current needs of humankind without harm to future generations. Sustainability includes three principles: first, balanced self-sustaining economic growth, based on efficient use and distribution of resources; second, harmonious social development, which implies equal access to social benefits, political responsibility; third, the solution of economic problems [2].

To measure the level and dynamics of sustainable development, assessments of a complex of economic, social, and environmental characteristics are used, including indicators of the economy's impact on the natural environment, energy intensity, and specific energy consumption [3].

It should be noted, that ensuring high values of sustainable development indicators is significantly influenced by the ability of companies and firms to carry out innovation activities and apply digital achievements. And high rates of economic growth correlate with a high level of development of the innovation environment, science, new technologies, and management methods [4].

At the same time, there is a widespread opinion, that the innovative activity of a firm is directly dependent on its size [5].

The innovative activity of firms is purposefully supported and developed by the principles of using the drivers of the digital economy. As a rule, they will include big-data, cloud technologies, the Internet of things, smart city concepts. At the same time, there is an increase in the share of services in the total volume of production, the development of the process of decentralization of resources, an increase in the number of instant transactions, the development of a shared economy, and institutional support of business [6].

It should be noted, that the influence of robots and artificial intelligence leads to a significant increase in labor productivity in the business environment and the economy as a whole [7].

To overcome the losses, caused by the coronavirus and achieve economic growth, the activation of industrial enterprises in the regions is necessary. The formed production specialization is called upon to play an instrumental role. It is, which forms the necessary approaches and directions for the development and distribution of productive forces. Along with the increasing role of concentration of employment in the field of information technology and finance, export-oriented production activity still remains the basis for economic development [8].

Regional location of production can be considered as an economic resource and an independent factor, that determines the competitiveness of the territorial economic system [9].

At the same time, the basis of the industrial orientation of the regions should be knowledge-intensive industries, based on modern technologies. Highlighting effective institutional mechanisms for digital development allows to determine the directions of increasing the competitiveness of regions In the conditions of overcoming the consequences of the spread of COVID-19, it is necessary to use additional sources of economic growth for this, increase innovative activity and reduce inequality in terms of digital development [10].

Considerable attention is paid to the classification of indicators, that form the digital innovation environment in the regions. As a rule, a subdivision is made into economic, demographic (social), infrastructural and other groups, depending on the characteristics of the study [11, 12].

The indicators of the innovative digital environment are fully determined by the industry regional specialization. These indicators depend on the number and direction of the sectors and directions, concentrated in them, the level of their development and the qualitative characteristics of enterprises, representing a particular sector. This determines the formation of opportunities for ensuring economic growth in the current crisis [13].

Meanwhile, the most universal and preferable model of regional development is its diversification [14], which contributes to the most versatile positioning of the region in the conditions of digitalization.

At the same time, the implementation of the paradigm of economic growth of regions, based on industrial innovation-active enterprises, will largely depend on the state of the territorial digital infrastructure.

Digital infrastructural capital, realized through access to broadband Internet, the intensity of the use of server equipment and local area networks at regional enterprises, has an elastic effect on the value of the gross regional product [15].

Meanwhile, the long-term impact of information and communication technology infrastructure and broadband Internet on real GDP, consumer prices index, employment, and gross fixed capital formation has been extensively studied in Western scientific literature. Among the latter, the works $[16,17]$ should be noted.

At the same time, trends for increasing the efficiency of territorial industry management and its development on the basis of the widespread use of information technologies are increasingly being formed in Russian regions. This allows to improve the management system by obtaining the necessary information by the managers of the management system from a single information center. At the same time, the decisions made have a high degree of consistency, and information about the current processes at the enterprise is promptly received by the management [18].

Improving the economic activities of enterprises and increasing their role in overcoming losses, caused by the impact of COVID-19, largely depends on the high-quality setting of financial management, based on the use of digital technologies, as well as capital expansion in the form of non-financial innovative products, based on engineering accounting and analysis of the results of material production and the widespread use of the essentials of the knowledge economy [19]. 
Dynamic gross regional product is a measure of overcoming the existing economic lag. It includes the results of investment in the development and implementation of digital technologies, the renewal of production equipment and an increase in labor productivity, which naturally leads to the economic growth of the territory. In this regard, this category should be the subject of increased attention of the authorities and business [20].

Table 1: Initial list of indicators

\section{RESEARCH METHODS}

To assess the dynamics of changes in the regional economies of the constituent entities of the Federation, caused by the COVID-19 pandemic, we propose to calculate an average indicator, that would characterize this area. For this, a number of indicators were selected, that reflect the industrial development of the territories of the Central Federal District (CFD) for the period of JanuaryJune 2020. The resulting list of indicators is presented in Table

\begin{tabular}{|c|l|l|}
\hline No. & \multicolumn{1}{|c|}{ Name } & \multicolumn{1}{|c|}{ Unit of measurement } \\
\hline 1 & Industrial production index & $\%$ (to the previous month) \\
\hline 2 & Power generation & Million $\mathrm{kW} *$ hour \\
\hline 3 & Manufacturing index & $\%$ (to the previous month) \\
\hline 4 & Retail turnover index & $\%$ (to the previous month) \\
\hline
\end{tabular}

It should be noted, that it is still difficult to assess the occurred changes more fully due to the fact, that data on all sectors are not published.

To assess the average trends, an index of industrial change was determined, determined in several stages:

- calculation of the normalized value - determined by dividing the actual data of the region by the maximum value for a given period for the subjects of the Central Federal District;

- determination of the aggregate index - calculation of the geometric variable, according to the indicators, indicated in table 1 ;

- correction of the resulting index by the veriable of digital development. It should be noted, that digital development will be formed according to a similar algorithm for 2019 . This approach is caused by a cumulative effect, due to which digital and network technologies do not give immediate results, but after a certain time perspective, for which one calendar year is taken in this study. The following were taken as the initial indicators: the specific gravity of organizations, that used the Internet; the specific gravity of organizations, that used personal computers.

\section{RESEARCH RESULTS}

The resulting total values are presented in table 2 . Analyzing the data in Table 2, we note, that seven regions showed a decrease in the index - Belgorod (-26.4\%), Vladimir $(-15.0 \%)$, Ivanovo $(-29.1 \%)$, Kaluga $(-1.6 \%)$, Lipetsk (-11.5\%), Oryol (-5.9\%), Smolensk (-0.3\%) regions. The rest of the constituent entities show the growth of this indicator. The leaders in the growth of the index are the Tula $(+38.7 \%)$, Yaroslavl $(+26.1 \%)$, and Ryazan (+24.3\%) regions.

We note, that the structure of the calculated index has a number of features. So, on the component, characterizing the retail trade turnover in all territories, the indicators are falling. The exception is Moscow, where the growth was $22.4 \%$. For the rest of the analyzed values, most of the constituent entities demonstrate an increase.

On the industrial production index, growth is observed only in 11 regions. At the same time, the leaders are Tula $(+108.1 \%)$, Yaroslavl $(+100.1 \%)$ and Tambov $(+45.5 \%)$, and outsiders are Belgorod (-21.4\%), Lipetsk (-21.0\%), Smolensk $(-13.2 \%)$ regions. The increase in power production is also taking place in 10 regions. The leaders are Kostroma $(+107.9 \%)$, Bryansk $(+98.3 \%)$, and Ryazan $(+89.9 \%)$ regions. The least optimal dynamics is observed in the Tambov (-41.3\%), Ivanovo (-66.5\%) and Belgorod $(-39.3 \%)$ regions. Assessing the manufacturing, we note, those positive dynamics was formed in 13 regions. The most optimal processes are in Yaroslavl $(+132.9 \%)$, Tula $(+121.9 \%)$ and Voronezh $(+48.9 \%)$, the least are in Lipetsk (-23.6\%) and Belgorod (-18.0\%) regions. 
Table 2: Industrial change index

\begin{tabular}{|c|c|c|c|c|c|c|}
\hline & January & February & March & April & May & June \\
\hline Belgorod region & 0.375 & 0.315 & 0.301 & 0.372 & 0.332 & 0.276 \\
\hline Bryansk region & 0.154 & 0.156 & 0.153 & 0.176 & 0.187 & 0.185 \\
\hline Vladimir region & 0.429 & 0.391 & 0.352 & 0.449 & 0.391 & 0.364 \\
\hline Voronezh region & 0.639 & 0.711 & 0.690 & 0.671 & 0.827 & 0.784 \\
\hline Ivanovo region & 0.394 & 0.396 & 0.295 & 0.327 & 0.310 & 0.279 \\
\hline Kaluga region & 0.232 & 0.239 & 0.219 & 0.193 & 0.237 & 0.228 \\
\hline Kostroma region & 0.494 & 0.474 & 0.410 & 0.432 & 0.481 & 0.540 \\
\hline Kursk region & 0.675 & 0.597 & 0.590 & 0.692 & 0.679 & 0.684 \\
\hline Lipetsk region & 0.526 & 0.437 & 0.421 & 0.517 & 0.528 & 0.466 \\
\hline Moscow region & 0.623 & 0.627 & 0.559 & 0.587 & 0.646 & 0.688 \\
\hline Oryol Region & 0.340 & 0.319 & 0.289 & 0.334 & 0.288 & 0.320 \\
\hline Ryazan Oblast & 0.398 & 0.441 & 0.401 & 0.454 & 0.437 & 0.495 \\
\hline Smolensk region & 0.690 & 0.629 & 0.622 & 0.759 & 0.785 & 0.688 \\
\hline Tambov Region & 0.294 & 0.327 & 0.300 & 0.331 & 0.301 & 0.301 \\
\hline Tver region & 0.688 & 0.750 & 0.653 & 0.777 & 0.842 & 0.818 \\
\hline Tula region & 0.346 & 0.509 & 0.505 & 0.359 & 0.502 & 0.480 \\
\hline Yaroslavl region & 0.406 & 0.564 & 0.529 & 0.527 & 0.536 & 0.512 \\
\hline Moscow & 0.852 & 0.883 & 0.796 & 0.856 & 0.876 & 0.884 \\
\hline
\end{tabular}

\section{DISCUSSION OF FINDINGS}

Summarizing the assessment, we note, that the proposed index for assessing industrial change in the regional economy allows to assess the dynamics for the period of January-June 2020. The industry shows some stagnation in most regions, but at the same time, there are also territories, where growth is taking place according to most of the analyzed indicators. Note that this trend is shortterm and at the moment cannot be fully assessed, since not all data are published. However, relying on the above data, it becomes possible to note, that catastrophic changes in regional economic systems in the industrial sector did not occur.

The given toolkit allows us to conduct an average assessment of current changes in the social and economic sphere and can be useful for all concerned parties.

\section{CONCLUSIONS}

Thus, the study of the significance of the use of digital technologies and information and communication networks in the activities of industrial enterprises contributed to an increase in the innovative production orientation of the regions and sustainable development. At the same time, the size of the enterprise matters, since the state of the innovative digital potential of the firm depends on its size.

In addition, the innovativeness of companies is developed and supported by the principles of using the drivers of the digital economy, and the use of robots and artificial intelligence leads to an increase in labor productivity in both production and business. The production specialization of the regions is important here as a 
condition for overcoming the lag, caused by the coronavirus.

The rational location of productive forces is an independent factor and a significant resource for economic development.

\section{REFERENCES}

[1] M. Vasiev, K. Bi, A. Denisov, V. Bocharnikov, How COVID-19 Pandemics Influences Chinese Economic Sustainability. Foresight and STI Governance, 14(2) (2020) 7-22. DOI: 10.17323/25002597.2020.2.7.22

[2] S. Zemtsov, V. Barinova, V. Kidyayeva, T. Lanshina Ecological Efficiency and Sustainable Regional Development in Russia During the 20 Years of Resource-Based Growth, Ekonomicheskaya Politika15(2) (2020) 18-47 DOI: 10.18288/1994-51242020-2-18-47

[3] S. Bell, S. Morse, Sustainability Indicators: Measuring the Immeasurable? London: Routledge, 2012.

[4] O.S. Mariev, K.M. Nagieva, V.L. Simonova, Managing innovation activity factors in Russian regions through econometric modeling, The Manager 11(1) (2020) 57-69. DOI: 10.29141/22185003-2020-11-1-6

[5] J.P. Pradhan, Liberalization, firm size and R\&D performance: A firm level study of Indian pharmaceutical industry, J. of Indian School of Political Economy, 14(4) (2003) 647-666,

[6] E.V. Popov, Business institutions of economic activity digitalization, The Manager 10(2) (2019) 2-10. DOI: 10.29141/2218-5003-2019-10-2-1

[7] C. Dirican, The Impacts of Robotics, Artificial Intelligence on Business and Economics, Procedia Social and Behavioral Sciences 195 (2015) 564-573.

[8] I. V. Grebenkin, Trends in Industrial Specialization and Development Dynamics in the Russian Regions, Economy of Region 16(1) (2020) 69-83.

[9] R. Capello, Regional economics in its fifties: recent theoretical directions and future challenges, Annals of Regional Science 42(4) (2008) 747-767.

[10] M. Yu. Arkhipova, V. P. Sirotin, Regional aspects of the development of information, communication and digital technologies in Russia, Economy of Region 15 (3) (2019) 670-683.
[11] K. Bagchi, Factors contributing to Global Digital Divide: Some empirical results, Journal of Global Information Technology Management 8 (3) (2005) 47 65. doi.org/10.1080/1097198X.2005.10856402

[12] M.D. Chinn, R.W. Fairlie, The Determinants of the Global Digital Divide: A Cross-Country Analysis of Computer and Internet Penetration, Oxford Economic Papers. New Series 59(1) (2007) 16-44. https://doi.org/10.1093/oep/gpl024

[13] E. Kutsenko, Y. Eferin "Whirlpools" and "Safe Harbors" in the Dynamics of Industrial Specialization in Russian Regions, Foresight and STI Governance, 13(3) (2019) 24-40. DOI: 10.17323/25002597.2019.3.24.40

[14] R. Boschma, Relatedness as driver of regional diversification: A research agenda, Regional Studies 51(3) (2017) 351-364.

T.V. Kramin, A.R. Klimanova, Development of digital infrastructure in the regions of Russia,Terra Economicus, 17(2) (2019) 60-76. DOI: 10.23683/20736606-2019-17-2-60-76

[15] D. T. Nipo, I. Bujang, H. Hassan, Global Digital Divide: Inter-regional Study on the Impact of ICT Diffusion on Economic Growth, In: Proceedings of the 2nd Advances in Business Research International Conference. Springer, Singapore, 2018. pp. 209-220.

[16] R. P. Pradhan, G. Mallik, T. P. Bagchi, Information communication technology (ICT) infrastructure and economic growth: A causality evinced by cross-country panel data, IIMB Management Rev. 30(1) (2018) 91-103

[17] A.A. Urasova, Regional Industrial Complex in the Digital Age: Information and Communication Dimension, Economy of Region 15 (3) (2019) 684-694. doi10.17059 / 2019-3-5

[18] V. A. Chernov Implementation of Digital Technologies in Financial Management, Economy of region16 (1) (2020) 283-297. doi.org/10.17059/2020-121

[19] K. N. Yusupov, Yu.S. Toktamysheva, A. V. Yangirov, R. R. Akhunov Economic Growth Strategy Based on the Dynamics of Gross Domestic Product, Economy of region 15 (1) (2019) 151-163. doi 10.17059 / 2019-1-12 